\title{
Problematics of Regulation of Voluntary Migration of Persons Displaced As a Result of Adverse Consequences of Climate Change within the UNFCCC Regime
}

\author{
Anastasia Vasilyeva \\ Department of International Law \\ RUDN University \\ Moscow, Russia \\ stasya_xax@mail.ru
}

\author{
Ekaterina Kiseleva \\ Department of International Law \\ RUDN University \\ Moscow, Russia \\ kiseleva_ev@rudn.university
}

\author{
Alexandr Solntsev \\ Department of International Law \\ RUDN University \\ Moscow, Russia \\ solntsev_am@rudn.university
}

\begin{abstract}
In order to combat the adverse effects of climate, as well as to arrange voluntary resettlement of the population of the sinking states, measures are being developed both at the universal, regional, and national levels. In this article, we will only consider the universal level of international legal regulation in frames of the Conference of the Parties to the UN Framework Convention on Climate Change of 1992 (hereinafter UNFCCC). As we can see, to date, the main international strategies for assistance to small island developing states in the context of climate change have a preventive focus, are aimed at implementing national adaptation programs with international financial support, and the issue of planning the migration of the population of the endangered small island developing states to other states is not being raised.
\end{abstract}

Keywords-Environmental migration; Climate change; International law; UNFCCC

\section{INTRODUCTION}

Migration of the population of states that are disappearing due to climate change is a normal display of the desire to save one's life. Considering the threat of the immersion of the territory under water being not partial, but full, such migration will take place not only inside disappearing states - from the lowland to the higher ground, but it will later become transboundary. However, the difficulty lies in the fact that the population of the sinking states will not be able to freely cross the borders of foreign states. There is no general rule of international law obliging states to host populations that have experienced the adverse effects of climate change. On the basis of the principle of sovereign equality of states, only the host state itself may take a decision to welcome the population of the endangered state either in accordance with the existing rule of international law binding on the host state, or based on its own ad hoc will for the particular situation in question.

\section{REGULATION OF VOLUNTARY MiGRATION}

The regime of state borders is permissive and notifying. Each state has the right, through its national legislation, to regulate access of migrants into its territory [3]. This is specifically emphasized in the international human rights law instruments (for example, Article 12 of the International Covenant on Civil and Political Rights of 1966).

The UN General secretary in his report "In Safety and Dignity: Addressing Large Movements of Refugees and Migrants" recommended "to support efforts by Member States at risk from the adverse impacts of climate change to mitigate those effects, and, where necessary, to plan for migration, including planned relocation, as a means of preventing and minimizing forced displacement" .

In order to combat the adverse effects of climate, as well as to arrange voluntary resettlement of the population of the sinking states, measures are being developed both at the universal, regional, and national levels. In this article, we will only consider the universal level of international legal regulation in frames of the Conference of the Parties to the UN Framework Convention on Climate Change of 1992 (hereinafter UNFCCC).

\footnotetext{
${ }^{1}$ UN Secretary General Report "In safety and dignity: addressing large movements of refugees and migrants". UN Doc. A/70/59. URL: https://refugeesmigrants.un.org/sites/default/files/sg_report_russian.p df (17.03.2018)
} 
There is no universal international agreement in international law that regulates voluntary migration of persons displaced due to the adverse effects of climate change. The threat to lose national sovereignty is a political issue in the agenda of the Conference of the Parties to the UN Framework Convention on Climate Change of 1992 (hereinafter UNFCCC) on dangerous climate changes [2]. However, the UNFCCC and the Conference of the Parties mainly focus on climate change mitigation strategies that involve reduction of sources of greenhouse gases or improvement of the quality of absorbers of greenhouse gases in order to try to slow down the adverse effects of climate change.

Nevertheless, there are developments in this area in the framework of the UNFCCC system. In 2010, the Cancun Mechanism for Adaptation to Climate Change was developed within the framework of the UNFCCC, which created an appropriate adaptation fund under the UNFCCC and identified three interrelated components over which it should work insurance, rehabilitation / compensation and risk management ${ }^{2}$. Further in 2012, the Work Programme on Loss and Damage was developed, which provides "measures for insurance of climate risks and establishment of an ad-hoc committee on adaptation".

Thus, in 2012, at the 18th Conference of the Parties to the UNFCCC and the 8th Meeting of the Parties to the Kyoto Protocol held in Doha, decisions were adopted that included migration issues caused by the adverse effects of climate change (COP. 3/CP.18). In 2013, the Conference of the Parties established the Warsaw Mechanism ${ }^{3}$, whose tasks are as follows:

- To enhance knowledge and understanding of comprehensive risk management approaches to address loss and damage associated with the adverse effects of climate change;

- $\quad$ To strengthen the dialogue, coordination, coherence and synergies among relevant stakeholders;

- To enhance action and support, including finance, technology and capacity building, to address loss and damage associated with the adverse effects of climate change.

Within the framework of the Warsaw International Mechanism for Loss and Damage from the Impact of Climate Change, a plan was developed for 2015-2016 on migration and research in this field ${ }^{4}$.

2 See: A.A. Khakhina. International legal mechanisms of responsibility for adverse consequences of climate change leading to flooding of the state territory // Gaps in Russian legislation, 2016. No. 8. - P. 410.

${ }^{3}$ UNFCCC Decision 2/CP.19, Warsaw international mechanism for loss and damage associated with climate change impacts, Jan. 31, 2014 // UN Doc. FCCC/CP/2013/10/Add.1.

${ }^{4}$ Report of the Executive Committee of the Warsaw International Mechanism for Loss and Damage associated with Climate Change Impacts // FCCC/SB/2014/4, Annex II. URL: http://unfccc.int/adaptation/workstreams/

loss_and_damage/items/8805.php. (Accessed on 22.01.2018).
At the 21st Conference of the Parties to the UNFCCC and the 11th meeting of the Parties to the Kyoto Protocol held from November 30 to December 12, 2015 in Paris, the Paris Agreement was adopted. In addition to the goal of reducing "global annual emissions of greenhouse gases by 2020 and aggregate emission pathways consistent with holding the increase in the global average temperature to well below $2{ }^{\circ} \mathrm{C}$ above preindustrial levels and pursuing efforts to limit the temperature increase to $1.5^{\circ} \mathrm{C}^{\prime \prime}[1]$, to help the developed countries to collect $\$ 100$ billion a year starting from 2020, in part through the Green Fund to assist combatting climate change, it declares that participating states "should, when taking action to address climate change, respect, promote and consider their respective obligations on human rights"[1].

The agreements adopted at the 21st Conference of the Parties in Paris provide for a mechanism for addressing the problem of human displacement associated with the adverse effects of climate change. Thus, paragraph 50 of Decision 1/CP.21 requests "the Executive Committee of the Warsaw International Mechanism to establish a task force to complement, draw upon the work of and involve, as appropriate, existing bodies and expert groups under the UNFCCC including the Adaptation Committee and the Least Developed Countries Expert Group, as well as relevant organizations and expert bodies outside the Convention, to develop recommendations for integrated approaches to avert, minimize and address displacement related to the adverse impacts of climate change"5.

This task force will have to adopt the programme as a more detailed and specific document and submit it to the conference of the parties for approval. Such mechanism will be more flexible than the mechanism of an international treaty, and will be able to quickly change and adapt to the situation.

Such program should contain the following main points ${ }^{6}$ :

- Criteria for identifying persons displaced as a result of the adverse effects of climate change who are eligible to get resettlement assistance;

- Basic requirements for temporary accommodation of persons displaced due to the adverse effects of climate change;

- Procedures that are mandatory for compliance by states hosting communities displaced by the adverse effects of climate change.

This group does not have the authority to impose international obligations on states, but it can nevertheless offer

\footnotetext{
${ }^{5}$ Report of the Conference of the Parties on its twenty-first session, held in Paris from 30 November to 13 December 2015. Part two: Action taken by the Conference of the Parties at its twenty-first $\begin{array}{llll}\text { session. } & - & \text { P. } & 9 . \\ \text { URL: }\end{array}$ http://unfccc.int/resource/docs/2015/cop21/rus/10a01r.pdf (18.03.2018).

${ }^{6}$ Wood T. Disasters and displacement in a changing climate. - P. 24.

URL: http://www.fmreview.org/sites/fmr/files/FMRdownloads/en/cli matechange-disasters.pdf. (22.01.2018).
} 
non-binding standards for states to deal with persons displaced due to the adverse effects of climate change.

In its resolution of 25 September 2010, the "Outcome of the High-level Meeting to Review the Implementation of the Mauritius Strategy for the Further Implementation of the Program of Action for the Sustainable Development of Small Island Developing States", the UN General Assembly (hereinafter UN GA) called upon the international community to "enhance support for the efforts of small island developing states to adapt to the adverse impacts of climate change, including through the provision of dedicated sources of financing"7.

The following funds are available as financial assistance to the endangered states for minimizing of the consequences of the adverse effects of climate change, as well as for development of adaptation plans at the international level:

- The Global Environment Facility established in 1991 that unites the governments of 181 states (including Russia) to solve global environmental problems in partnership with international and non-governmental organizations, as well as with the private sector.

- The Special Climate Change Fund established in accordance with the UNFCCC in 2001, as a complement to other funding mechanisms for implementation of the Convention, managed by the Global Environment Facility.

- The UN Green Climate Fund established in 2010 by 194 states-participants of the UNFCCC; the participants agreed to collect about $\$ 100$ billion for development projects of developing countries. The Fund has already allocated more than $\$ 60$ million for the reconstruction and construction of fresh water supply infrastructure.

- The Voluntary Trust Fund for the Participation of the Least Developed Countries and Small Island Developing States also managed by the Global Environment Facility, and its funds are directed to the preparation and implementation of national action programs for adaptation to climate change in small island developing states. Thus, during the period from July 1, 2014 to June 30, 2018, the following states received material assistance for the development of national action programs for adaptation to climate change: Tuvalu - \$6 million, Kiribati - \$6 million, Maldives - \$ 6.66 million, Marshall Islands - \$ 4.58 million, Vanuatu - \$6.78 million, Solomon Islands \$ 8,52 million dollars, the Bahamas - \$7,54 million.

- The Adaptation Fund established under the Kyoto Protocol of the UNFCCC to finance specific adaptation

\footnotetext{
${ }^{7}$ Resolution adopted by the General Assembly on 25 September 2010 "Outcome document of the High-level Review Meeting on the Implementation of the Mauritius Strategy for the Further Implementation of the Programme of Action for the Sustainable Development of Small Island Developing States // A/RES/65/2 URL:https://documents-dds-

ny.un.org/doc/UNDOC/GEN/N10/512/68/PDF/N1051268.pdf?Open Element (22.01.2018).
}

projects and programs in developing countries that are parties to the Kyoto Protocol and are particularly vulnerable to the adverse effects of climate change. Since 2010, the Adaptation Fund has allocated \$ 354.89 million to support 61 states, including 22 least developed countries and 13 small island developing states.

According to the Barbados Program of Action for the Sustainable Development of Small Island Developing States of 1994 (adopted at the 1st International Conference on Small Island Developing States), the Mauritius Strategy for the Sustainable Development of Small Island Developing States of 2005 (adopted at the 2nd international Conference on Small Island Developing States), the "Samoa Pathway" of 2014 (adopted at the 3rd International Conference on Small Island Developing States), as well as a number of the UN GA resolutions $^{8}$, the following steps should be taken in order to strengthen the efforts of small island developing states in their struggle against the adverse effects of climate change:

- To increase global promotion of implementation of the UNFCCC principles (para. 19 of the Barbados Program, para. 8 of the UNGA Resolution of September 25, 2010, A/RES/65/2, para. 17 of the Mauritius Strategy, para. 35 of the "Samoa Pathway");

- To support national efforts aimed at developing strategies and measures on facilitation of the consequences of climate change and adaptation to them (para. 19(C)(vii) of the Barbados Program, para. 9 of the UNGA Resolution of September 25, 2010, A/RES/65/2, para. 18(g) of the Mauritius Strategy, para. 18 of the "Samoa Pathway");

- To provide broad access to specialized sources of funding (para. 10 of the UNGA Resolution of September 25, 2010, A/RES/65/2), at least $50 \%$ of the resources of the Green Climate Fund should be used for adaptation purposes for especially vulnerable countries (paras. 15 and 44 of the "Samoa Pathway");

- To ensure the transfer of appropriate technologies for responding to climate change (para. 10 of the UNGA Resolution of September 25, 2010, A/RES/65/2, para. 18(e) of the Mauritius Strategy);

- To raise awareness of the need for urgent and largescale action to address climate change (para. 33 of the "Samoa Pathway");

- To improve the baseline monitoring of island systems and the downscaling of climate model projections to enable better projections of the future impacts on small islands (para. 44 of the "Samoa Pathway").

8 A/RES/S-22/2 [Electronic resource]. - Access mode: http://www.un.org/ru/documents/decl_conv/declarations/isldecl.shtml (Accessed on 22.01.2018); A/RES/65/2 [Electronic resource]. Access mode: https://documents-ddsny.un.org/doc/UNDOC/GEN/N10/512/68/PDF/N1051268.pdf?Open Element (Accessed on 22.01.2018). 


\section{CONCLUSION}

As we can see, to date, the main international strategies for assistance to small island developing states in the context of climate change have a preventive focus, are aimed at implementing national adaptation programs with international financial support, and the issue of planning the migration of the population of the endangered small island developing states to other states is not being raised.

\section{ACKNOWLEDGMENT}

The paper is prepared under the project "Creating a model of a multifunctional centre of competencies in social work with migrants under conditions of their growing inflow in Russia and Switzerland to mitigate threats to society, economy, the state" funded by Ministry of Education and Science of Russian Federation. Project is realized at Saint Petersburg State University under the support of the Federal Target Programme "Research and Development in Top Priority Dimensions of the Science and Technology Complex of Russia in 2014-2020". The Project ID is RFMEFI61317X0072.

\section{REFERENCES}

[1] Abashidze AH, Solntsev AM, Kodolova AV, Kruglov DA, Petrova NA. International environmental rights: documents and comments. Tutorial. Issue. IV. International legal protection of the atmosphere, including the ozone layer, and outer space / Moscow, 2018. P.188. (In Russian)

[2] Barnett J. and Adger N. Climate Dangers and Atoll Countries, 2001. URL:http://tyndall.ac.uk/sites/default/files/wp9.pdf (22.01.2018).

[3] E.V. Kiseleva. International legal regulation of migration. Textbook for undergraduate and master's studies. 3d edition, updated and revised. Moscow: Uright, 2017. - P. 252. 